\title{
Plucky Lads and Succubi: Fin de Siècle Masculinity in Kim, Peter Pan and The Turn of the Screw
}

\author{
Lucy Hamilton
}

$\mathrm{W}$ ith the amalgan 'hunter-fighter-fucker' Norman Mailer has, in typical climactic shudders, beaten out his conception of grunting masculinity (Millett 1977, p.327). Others deny gender polarization, basing their construction of masculinity wholly on socialized difference. Ideas vary across time and relate to many factors within a society; Renaissance English society saw sex boundaries as permeable and allowed a comparatively 'feminine' aspect to male behaviour and attire. The love of 'boys' was considered acceptable but not 'the abominable crime of sodomy' (Orgel 1996, p.38). Fin de siècle English society, however, revolved around the overwhelmingly homosocial worlds of Public School, Universities and Clubland.' Homosexual behaviour, so threatening within these male worlds, was pathologized to reinforce the boundary between hypermasculinity and homoeroticism (Showalter 1991, pp.11 \& 94). The construction of gender, figuratively and literally, within the texts of Kim, Peter Pan and The Turn of the Screw reflects this.

Discourses of gender intersect with those of the rest of the spectrum by which humanity constructs itself. Femininity and 'Childhood' have many overlaps, with women often having been cast as child or childlike, whatever that is needed to mean. Masculinity, particularly white middleclass masculinity, is usually constructed by marking off its difference from many forms of other: feminine, racial, class and child (Cranny-Francis 1992, pp.71-1 16). All are figured in similar terms: opposite and inferior; silent because spoken for; irrational and dangerous (Nodelman 1992, pp.29-35). Thus the intersection of man and child in 'the boy' in literature is a site rife with drama and signification; the passive, ruled, and empty is to be transformed into its other, active, dominating and knowing.

The 'child' of the nineteenth century is not as simple to pin down as we had liked to think (Kincaid 1992, pp.61-103). A pair of discourses dominates attitudes, however, very loosely identifiable as 'Original Sin' and 'Original Innocence' (Leavis in Coveney 1967, p. 17). The Puritans, as reformers, brought the 'child' and its potential into focus. In this version, it (neutered) is perceived to arrive loaded with the taint of Eve's Original Sin, to be educated or beaten into individual redemption and the salvation of society. The harsher face of this Bunyan expressed: 'We are Transgressors from the Womb, and go astray as soon as we are born... The first things that bloom and put forth themselves in Children, shew their Ignorance of God, their disobedience to Parents, and their innate enmity to Holiness of Life' (Carpenter 1984, p.432). Then Rousseau placed 'on the child's shoulders the responsibility for saving humankind from the degeneracy of modern society' (Rose 1992, p.43) through nature; the Romantics, rejecting biblical injunctions, pictured that 'child' as 'Innocence', as the purity of man's idyllic origins, before entering the prison of experienced adulthood. The child could be used to express revolutionary sentiments and dissatisfaction with the mechanized and utilitarian present, symbolizing Imagination, Sensibility and Nature (Coveney 1967, p.31).

Darwin's revelations shattered traditional theistic and anthropocentric understandings of humanity, but evolutionary theory also fed into various strands of Victorian discourse concerning children. Each child could be seen to recapitulate man's joumey from savagery to civilization. It is this understanding of a move to civilization (salvation for those with a religious bent), that suggests how the two discourses intertwine. Within the same society, often within the same minds, the child was innocent and savage simultaneously. It was the role of the surrounding adults to preserve the innocence or 'manage' the savage so that the inevitable progress of humankind towards 'perfection' might continue. This thought must be held at the same time as the comprehension that as many as half of the working class children bom died before reaching five years of age, and many of the vilest and most dangerous occupations of the time were the province of children (Kincaid 1992, p.75).

The growth of the British Empire is particularly significant during this period. Not only was mankind to develop towards its zenith, but the zenith was to be British and each Briton was to be fit to contribute to the running and controlling of the structure. The female needed to be virtuous and nurturing; the role of the male however was crucial to remaking the globe in the image of this creature astride the evolutionary ladder's top rung. This man, into whom British boys were to develop, has been described as 'homo newboldiensis' (Howarth 1973, p.14) and, above 
all, he was 'manly'. This involved aspiring to upper middle class values like loyalty, conformity and success, recognizing the importance of duty to one's country and a 'tendency towards philistinism in artistic taste' (Howarth, p.14). Women were treated with theoretical respect and actual suspicion. While a man ought to be skilled and able to help his chums out in a tight comer, any hint of intellectual prowess was to be scotched. A Darwinomarxist comprehension of progress as conflict led to a valorization of combat (Howarth, pp.13 and 174). So from the beginning of the nineteenth century, when boys had been taught to value prudence, diligence and industry with the aid of 'Awful Examples' and to understand men who enlisted to be fools and most probably rogues (Avery 1975 , p.167), the expectations facing boys had altered considerably. Great hopes rested upon these Boys of Empire, who were to rule the world, and their reading material was one of the prime tools used in their building.

The three novels are dominated by many of these Victorian threads. Auerbach has characterized the boys presented in Victorian literature as 'allied to the animal, the Satanic and the insane'; aspects of these can be detected in Kim, Peter and Miles. Her central argument therefore places the boy's novel as Bildungsroman or developmental novel, but is only partially valid $(1989, \mathrm{p} .414)$. The opposite was also possible, with characters devolving towards discredited deaths. Others, like Diamond in At The Back Of The North Wind, are stable; he is described as 'God's baby' and able, like many saintly girls of the century, to die young, trapped in pre-sexual immaculacy and beauty. The two types of story which dominate the field for young men, once early didactic efforts were abandoned in the realization that boys wouldn't read them, were the school story and the adventure story. The former has a generic tendency towards the evolutionary as the protagonist overcomes initial forays into vice or misdemeanour to triumph as sound and hearty captain of the cricket team. The adventure story also involves survival, but while the protagonists usually gain skills, their own development may not be terribly significant. In the formula novels churned out for Christmas and the 'bloods' (racy magazines), the boy hero was a figurine to perform fabulous feats in the guise of the ideal Briton.

The three texts chosen, however, do not belong to the
Victorian period; although Kim, Peter Pan and The Turn of the Screw evolved out of the boys' literature of that period, they display also the anxieties of the fin de siècle. While the Empire remained at the core of experience into the twentieth century, the losses experienced in its first few years, conflict with European enemies and colonial unrest began to undermine the certainties that flowered in the height of the empire upon which the sun never set. Other factors can be seen to colour the image of the male in this period: Showalter characterizes masculinity as being in crisis, reacting to the development of feminism and the dreadful eruption of the 'New Woman'. Retreat into male territories and the corresponding necessity that men could be trusted not to blur the lines between appreciation of wholesome masculinity and the beastliness of homosexuality led to some difficulties regarding what men should be, how they attained manhood, how they should deal with women and whether it was really worth growing up at all, taking these factors into consideration. ${ }^{2}$ While the Bildungsroman certainly remains an element in the tale of the boy growing up, these anxieties about what he should be developing into provide a fascinating gloss on the tradition.

Kim is a Bildungsroman most clearly in the economy of knowledge that underpins the text. Intertwined with the Indian location, this marks the tale as a colonial text; the colonizer's ambition is 'to know, to appropriate and to rule' (Boehmer 1995, p.20). Knowledge is desired for its own sake as well as to assist in reinforcing the conqueror's rule. Kim is a liminal figure, a lynchpin between the colonizer and colonized. He is analogous to the figure of the 'Coming Man' (Dixon 1995, p.93) in the 'White Colonies' who combines the most useful skills of the native race with all the best attributes of the British master race. Kim is the innate and skilled watcher, tying him with the masters of clear vision. Kim can rise above the divisions and limitations of the indigenous peoples by virtue of his Sahib elements, leaming by watching and listening, enabling him to mediate through the love shared with various native figures (Plotz 1992, pp. 16\&18).

Knowledge is presented in two paradigms. Teshoo Lama's knowledge is that of the holy fool; it is so freely given that it sends his hearers to sleep. ${ }^{3}$ His naivety and truth-telling 
mark him as 'mad' (insane) to fellow travellers. Better characterized perhaps, as wisdom, it is meant to free Man from the Wheel; this aspect is given a priority over the other form by the novel's closure, with the Lama smiling 'as a man may who has won salvation for himself and his beloved' (1996, p.380). The other knowledge is dislodged, hoarded and bartered; it is figured as power and is the worthwhile aspect of colonization within the text's moral structure. The work of the soldier is necessary and valued, that of the merchant irrelevant; both are infinitely less skilful and intriguing than the work for which Kim is being trained - spying - and which is not finally dismissed by his imminent salvation.

So Kim's development is partly into manhood - the kind that is virile and untarnished by the diminishments of Metropolitan living or the dangers of 'Oriental' culture; it is also, partly, a development into spirituality. In some ways, particularly pertinent given the degree to which he is the forerunner of something new, his progress is towards self-knowledge: 'Who is Kim - Kim - Kim?' (p.243) His identification with the Sahibs is sporadic; justly, since the British perceived the Irish as a form of white chimpanzee (Kingsley in Howarth 1973, p.25), and his sense of belonging to India is also fraught. The power infused into his personality in overcoming devolutionary terrors regarding 'going native' is explosive. It is uncertain whether this is a vision Kipling dared to see or whether it was allowed only in the 'felicitous space' of childhood (Bachelard in McBratney 1992, p.278).

Kim has the licence of class also, being white, but 'a poor white of the very poorest'. The first sentences of the novel highlight the contrasting possibilities this endows. As white and male, he sits astride the phallic weapon, Zam Zammah, 'always first of the conqueror's loot' (p.1), with the 'justification' of victory, but as child and non-English he has licence to break the rules, doing it 'in defiance of municipal orders'. Initially he runs wild, animal-like, in a parody of Rousseauian models of education and is often identified as animal: colt (tamed to British sporting needs), monkey and elephant calf (pp. 149, 167, 216). He had been 'kicked as far as single letters, but did not think well of them' (p. 130), and his illiteracy links him with Rousseau's distrust of the written word. Yet he is removed from the recommended pastoral setting, exposed to all the dissipated ills that most writers of the time seem to link to the idea of 'city'. Instead of being shielded from sexual matters and the written word, both of which deform the innocent child, he carries billet-doux between lovers. His addict father and addict mother-substitute 'nurture' him through boyhood. Nonetheless, Kim is not significantly tainted, as is indicated by his capacity to become the apple of his Lama's eye (p.136).

His progress is marked by child's work: playing; but the malleability he shows in dressing up is morally suspect, linking him to the satanic. A 'demon' in him rejoices in entering 'another's soul' (p.208) and the game takes place with the help of prostitutes and hellish spells. Games of the mind, such as his battle with Lurgan Sahib (where European language and mathematics conquer Oriental mind-tricks), and the Play of the Jewel, also figure in his education to become the greatest player in the adults' Game, for a thousand years (p.219). Far more is at stake in Kim's playing than the games played by the English boys growing up in the Mother country. Motherless Kim's games prove to be a matter of life and death, as his role in the "Great Game' becomes ever more significant. The playing fields of England are meant to be the training ground for British youth to develop pluck (Avery 1975, p. 195) which is to be manifested upon the battlefields of Empire. Boys all over the Empire could hope for little more adventure in their future than Kim's unimaginative guardian, the Drummer Boy, whose tales are told in 'insipid, single word talk' (p.162). Kim's romance must have shaped their dreams.

The women of $\mathrm{Kim}$ point to the anxieties expressed so widely in writings of the turn of the century and in Kipling himself. Kim's mother is killed off immediately; a female opium-addict leads his father to death. From the first 'Flower of Delight', women are characterized by their sexuality, immorality and danger. The Kulu Woman and the Woman of Shamlegh both convey something of the threat of the New Woman, haranguing and rebuking; they are intrusive and masculine in their forwardness and in their power, aiding yet offending with their patronage. The Woman of Shamlegh in particular threatens Kim because she possesses the eyes, bold and bright, that show the reader Kim's physical growth into an alluring specimen, 
and she makes the overt sexual advance that can be seen to propel Kim into his breakdown. The Widow irritates with a tongue that clacks 'as steadily as a rice husker' (p.98). Still sexual but beyond the age of danger, woman is admitted to be 'intensely human' (p.85). There are 'but two kinds of women in [the world] - those who take the strength out of a man and those who put it back', and the positive element of the dichotomy allows her to be termed 'Mother' by $\operatorname{Kim}(p .362,364)$, as healing as Mother Earth itself (p.372). The youth, however, manages to avoid the emasculating grasp of the female-feminine, safely within the nurturing male-feminine principle embodied by the Lama, who is both mother - virtuous and nurturing, passive and unworldly - and father - provider and taleteller, warrior and sage - to Kim. Kipling has constructed what appealed to so many men at this period: male mothering (Showalter 1991,p.78).

Kipling has taken the adventure story that sold magnificently throughout the late nineteenth and early twentieth centuries and, by reducing the age of the boy experiencing the exotic adventures of Empire, assisted it in becoming more overtly a children's book. The line is barely noticeable though; all these texts were meant to appeal to big and little boys. Perhaps it is that the boys themselves never really grew up in their rejection of a domestic and feminized sphere.

Peter Pan embodies this characteristic: ' $I$ just always want to be a little boy and to have fun' (1994, p.158). The resonance that he has carried through much of the twentieth century suggests the strength of this impulse. His Bildungsroman can't get a foot through the barred nursery window. This is a world where the ticking clock threatens to devour you, like the vagina dentata (Fiedler 1962, p.242), a world where to be trapped in the child's id offers the only escape from the threatened sterility of the father's role. There's no Romance in the post-romance world of domesticity; once the woman is wooed and won, man is relegated to the wage-slave role of bread-winner and disregarded where he ought to be master. Wendy, who is only needed in Neverland to be a 'nice motherly person', cannot avoid growing up to practise her mothering skills in earnest, interchangeable because a role not a person. Peter Pan runs away from his mother when he hears her plans for his adult life. School, while remembered fondly by the social-climbing Hook, proves to be dull stuff for the Lost Boys and the Darlings where they lose their imaginations, passing unnoticed through their formation into Tom Browns and then the hollow professions of their grown-up selves. Together with the embodiments of adulthood in the Darling parents: she is loving but weak and blind, he more selfdeceiving, and hypocritical to boot, with his "fatal gift of humour' ( $p .23$ ), the process looks eminently to be avoided neither male nor female option is to be desired.

The homely function of breadwinner fails to excite; the form of masculinity into which Peter appears to be choosing to develop (should he prove able) is that of Hook. The links between the two in oedipal terms are simple to establish (Egan 1982, pp.37-55). Alternatively, Hook is the adult Pan. When Peter fools the pirates with his imitation of their chief, Hook begins to doubt his own existence: 'He felt his ego slipping away from him' (p.125). The 'cock-y' boy turns him into a 'cod'-fish. In blood-thirst, the apprentice can compete, having killed 'tons' and regularly 'thinning out' the lost boys' numbers, paralleling the Pirate's casual murder of Skylights. After Hook's death, at the teeth of time (compared to Peter's prized 'little pearls'), Pan takes on the Captain's life, clothing and manner, treating his 'men' as dogs (p.213 cf p.76). Even the detail that 'for a moment Hook entranced' Wendy (p.169) implies his doubling of Pan, her play husband/son. The main contrast lies in ethics: Hook ostensibly acts according to the principles of 'good form', leamt at 'a famous public school'. These involve matters of correct dress and the like, and 'you have to prove you don't know you have it before you are eligible for Pop' (p.188). The moral element is absent as displayed in the massacre of the Redskins; Peter, on the other hand, continually puts his life at risk in the determination to avoid anything that 'would not have been fighting fair' (p.128).

Peter's emphasis on faimess, an element of his eternal childishness, is linked to the fact that everything must relate to the games he plays and 'Peter could never resist a game' (p.125). To kill or not is a game; to eat or to pretend is a game; to play father must only be a game. Even playing at dull sublunary life provides a game for Peter, doing nothing on a stool and coming back from walks 'without having killed so much as a grizzly' (p.111). War is, 
perhaps, the ultimate game. One of Peter's peculiarities is that 'in the middle of a fight he would change sides', able, like Kim, to 'go native'. That the 'real' redskins, 'fascinated by Peter's methods, agreed to be lost boys for that once, and so at it they all went again, more fiercely than ever' (p.111), works to subvert the almost sacred aura attached to the martial calling and patriotism.

In this boy's paradise, women's sexuality can have its fangs removed if you rename the virago 'Mother', but even mothers hold a deeply arbitrary value. They are castigated for gormlessly waiting, then again for barring the window too soon. They are continually desirable to this undifferentiated male, who returns to the nursery, even bringing the domesticating influence to send him to bed early in his unconscious. There is, however, something deeply disturbing about these replicating images of adult motherhood gathered, like vigilantes, around the id. There are more thoroughly happy moments of domestic gaiety in the Neverland than in the Darlings 'real' home, where a child is more likely to be given away than abruptly replaced.

In his innocence of sexuality and his unthinking savagery, Peter Pan embodies the archetypal Victorian rhetoric of childhood. He also lives in a parody of the Rousseauian educational setting, without the guiding adult whom Kim gains in the larna. Indeed The Coral Island freed the Robinsonnade from the 'all-wise all-explaining father' (Green in Richards 1989, p.47). Another link to Rousseau, again paralleling Kim, is the protagonist's literacy: Peter is 'the only boy on the island who could neither write nor spell - not the smallest word.' It is not overtly considered a deficiency: he is 'above that sort of thing' (p.109). Peter Pan links to that same Romantic perception of childhood as a time connected to man's earliest history as recorded in folktales, and nature, with only a vale of tears ahead.

If an essential element to the Bildungsroman is the acquisition of knowledge, then Peter is endlessly barred by his inability to remember characters and events. He is made helpless before the villainous Hook, by his repeated induction into 'unfairness': 'No one ever gets over the first unfaimess; no one except Peter'. That he often met it, but always forgot was 'the real difference between him and all the rest' (p.128). That Peter should forget Wendy is vaguely predictable; it is deeply unnerving, however, that on being reminded of Tinkerbell, he should say "There are such a lot of them'; not to mention his forgetting Hook (p.233). For Fiedler, Peter is Pan: not only a 'callous, amoral, vain boy, but a "devil"' (p.242); it is perhaps this demonic portrayal of childhood combined with lashings of sentimentality which makes this text so ambiguous. Peter $P a n$ is perceived on one level as the ultimate (canonical) classic for children, but it is also deeply subversive, as Rose points out, because of the slippery narrator who 'veers in and out of the story as servant, author and child' (p.73) and by the degree to which the tale delivers a deathblow to that staple of children's literature: the 'seadream' (Blake 1977, p.78), or wrecked island adventure story.

For the world over which he lords it is indeed that colonial island setting, even if it only comes to life when '[f] eeling that Peter was on his way back' (p.71). 'Oriental' tyranny (Phillips 1993, p. 174) is the nature of his rule: when Peter pretends to eat, no one eats and "his band were not allowed to know anything he did not know' (p.74). The island had been the focus of imperial fantasy since Robinson Crusoe and this one features all the necessary attributes, gathered from all the boys' adventure literature with savages, wild animals and pirates. Women like Wendy, Tinkerbell and Tigerlily bring nasty taints of sexuality into this portrait of the male unconscious, but luckily the 'Great White Father' is able to remain blind to their intentions, continuing his colonial adventure.

Another tale that sets its action on a version of the Island is The Turn of the Screw. This text, however, is written for adults, using all the explicit knowledge of psychology which Freud's work had brought to light as well as the tales of spirituality and psychic research which provided such a fertile field for study in the period. The piece was published as a serial in an American magazine, intended for consumption around the domestic hearth in the time approaching Christmas. The depravity implied within the children, the warden-like stare of the unreliably narrating adult, the disappearance of 'home' and the abandonment of the reader in the secondary world all sign this text as a work for adults. In addition to this, the complexity of the series of screens which refract and complicate the already 
sophisticated prose clearly signal its intended audience, so that the role of the children in the text differs significantly from those in texts intended for children.

So far as this is a Bildungsroman, the protagonist must be the Govemess whose psychological development pervades the central narrative. While she develops, it is not straightforward to pinpoint into what. She has been read as a vampire, sucking on the children's emotions and youth, as well as a lonely adolescent dealing with a complex, otherworldly threat. Unlike Kim and Peter who have rejected the recognition of their own sexuality, able to be perceived by women within the text, but not by themselves, the Governess is prefaced as 'in love' before the reader actually encounters her. She describes her own attraction to the Master of Bly: 'I was carried away in London' (1986, p.154); and her trials throughout the text are read by many to be the hysteria induced by sexual repression.

Like $\mathrm{Kim}$ this is a novel of education but, mimicking Jane Eyre, told from the consciousness of the adult who teaches, not the child who is (or avoids being) taught. However, Jane is rewritten by a man with ambivalent feelings about women and a distinct dislike for women as writers (Showalter 1991, p.77). The concept of Governess remains fraught, ranging from Charlotte Bronte's observation that the private governess was not 'considered a living rational being', to later Victorian anxieties regarding her role as conduit for or bulwark against vice (Lustig 1994, pp. 137 \& 186). Refusing her a name further undermines this Govemess's subjectivity. She may not presumptuously aspire to snare the Master and succeed (not even the crippled version). While Douglas implies she seems perky enough in later years, this novella concludes with her almost demented and having apparently killed the only male she is able to touch. For safety's sake the novelist has only allowed her the male as prepubescent, although apparently not pre-sexual. Sadly for the male, this is clearly not enough to protect Miles, who almost certainly dies under the onslaught.

Then again, the masculine principle leaves a lot to be desired in The Turn of the Screw. Embodied by the Uncle, he is present only as an absence, paying his 'highest tribute to a woman' by the 'more festal celebration of one of the sacred laws of his comfort' (p.214), translatable as a complete disinterest in this domestic world under his guardianship. He, like many other men of his class, abandons this world for one of men and sexually disposable women. In Quint, the same principle becomes more clearly vicious when imitated by a member of the lower classes. Interestingly, most of the critics so ready to hound the Governess as monstrous (monstress?) find no fault in a man whose care of his young relatives is so perilously cavalier.

Miles and Flora seem to embody some kind of male and female principle as implied by their names, 'Soldier' and 'Flower'. Flora is minimally characterised. Usually 'angelic' or 'one of Raphael's holy infants' (p.154), she is perhaps too much the child or infant, too vacant to be considered significant, with her 'hair of gold and her dress of blue' (p. 155). Innocence here is forced to expose itself as perception, not fact, enforced and emptying, a void waiting to be filled (Kincaid 1992, pp 13\&14). Meaning is poured into her, linking vacancy and the angelic. Of Flora's brother the governess writes, equally applicably: 'I could reconstitute nothing at all, and he was therefore an angel' (p.168). Miles, however, is older; his exit to school suggests his graduation from the un- (or less-) gendered world of childhood' to boyhood proper. When you consider the deeds and misdeeds allowed the other boys in their schoolboy novels, the mind boggles to perceive what act could cause such a peremptory foreshortening of Miles's own story. Just as we have coloured expectations when first encountering the Governess, the letter of expulsion taints the meeting of the reader, as well as the narator, with Miles. But swiftly we are reassured through her perceptions. Childish beauty is, not by any means for the first time in history, assumed to be synonymous with goodness; his 'sweetness of innocence' and 'positive fragrance of purity' (p.161) are determined by looking at (or perhaps smelling) him. The vacancy of 'child' is filled.

Later, the vacancy is re-filled as possession, with the same signs read to establish depravity (Lustig 1994, p.174). Fiedler points out that possessed children are objects of horror as gateways, allowing the satanic to enter the adult world. The satanic is merely, in this reading, 'another word for the impulsive, unconscious life otherwise called 
innocent' (Fiedler 1962, p.242). The Puritanical reading has overtumed the Romantic, the tabula rasa is stained. Here the Rousseauian education by nature has truly been spoilt by the intrusion of unnatural leaming within the idyll. Whether that unnatural leaming is of the depraving kind - sexual - or merely unsoundly bookish, it is difficult to determine.

Miles, like Kim, is something of a chameleon. Kim delights in the game of losing himself; with Miles, it is more as though there is no self ultimately to conceal. Miles's time is filled with play-acting and the setting of games to test the Governess; whether his game-playing is 'depraved', 'innocent' or somewhere between, is not defined and the reader balances on the razor's edge. Just as Peter Pan plays with the tropes of boy's fiction, so Miles's story at one time or another could belong to most other genres of boy's story. The tale of his schoolboy novel remains mysterious. The reader is left to ponder whether, like most of the boys, he would evolve to become a fine specimen of manhood (and usually they were redeemed) or whether he would devolve, like Eric, and risk his own death. Sometimes the Governess presents him as the perfect child and sometimes the brute: he could be Sandford or Merton. His adventure story is hinted at when he gains his 'freedom', roaming the countryside that surrounds this anti-Crusoesque island in the pastoral setting, or in his desire to know more of the world. Robert Louis Stevenson defined the boy's romance as something that turns 'not with the slips and hesitations of the conscience, but on the problems of the body and of the practical intelligence, in clean open-air adventure' (Blake 1977, p.166). The contrast with the Govemess's novel couldn't be more marked. When he lies in bed a 'wistful patient in a children's hospital' (p.226) his death is foretold, in terms that bring to mind the many deathbed scenes of Victorian literanure.

Miles speaks with the voice of a bachelor uncle, perhaps learnt at second hand through the man's valet: 'You know, my dear, that for a fellow to be with a lady always -!' (p.216). It is in this passage that we might be able to determine something of Miles's alteration; he is no longer willing to be reabsorbed into the feminine, quasi-maternal world of the nursery. He has reached the point where he must return to the masculine world, with his own sort, to learn more, to see 'more of life' (p.217); this is an act which the govemess can only perceive as evidence of his corruption, although Freud could explain it without trouble. However, the concept of development in this boy is barely relevant. We know that he is capable of wrong-doing because of his lies, impudence and because he provoked his expulsion. After a long period of apparent perfection, he acts to show his warden that he could be bad: 'And I can again' (p.216). This child may have evolved from vacant angel to youthful rake or satanic victim of possession; then again it could be that the Governess endows him with demonic significations. In this piece of adult fiction, the child is used to locate meanings; his character is barely to be determined and of questionable relevance. He presents nothing unmediated because of the complicated series of narrative frames within which he is viewed. Most of his appearances can be as easily labelled 'divine' and 'infernal' as the piano-playing scheme (p.232). With the child these are apparently interchangeable.

However disparate these three works are in terms of male development, they converge strongly in the degree to which they are tainted by the anxieties of fin de siècle society. Kim rejects women and almost any possibility of value in the female-feminine principle. The Turn of the Screw is a tale of paranoia raging against the power of the New Woman, where the male is killed by the relentlessness of her embrace. Peter Pan is trapped in his child's id, as the only place he can fend off the sexually predatory nature of the adult woman. All are fierce enough in their masculine abilities, all linked to the wartior in one way or another, but all are placed in grave danger from the everstrengthening band of women. All in some way remake the Robinsonnade, constructing an island that is or should be free of women. In this genre the only role a woman has is the waving of hankies as the adventurers come and go (Green in Richards 1989, p.45). Wendy is allowed to darn socks, native women to nurture and provide, but if you let a powerful woman become mistress on your island, Man, you are dead.

\section{NOTES}

1. These institutions belong, of course, to the upper and middle classes, although the avoidance of 'feminine' worlds can be seen also in Working Men's Clubs, 
which were of considerable importance to the educational and social worlds of the lower classes.

2. It might be interesting to note in the light of this retreat further into the world of the male, that the standard school story is rejected by all three male authors. Kipling (glossing over Kim's schooling as it glosses over the boy) writes, 'The record of a boy's education interests few save his parents' (p.214); James has his governess dismiss the 'little horrid unclean schoolworld' (p. 168) and Barrie's lost boys reflect 'Before they had attended school a week they saw what goats they had been not to remain on the island' (p.23I).

3. Teshoo Lama also provides Kim with his training in physical endurance. After leaving school, he suffers his test of fortitude as he battles with his physical limitations through the chasms and cliffs of the Himalayas: he limps, sweating and panting and 'aching in every fibre, dizzy with looking down, footsore' (pp.301-4). This is particularly humiliating to the fit and irrepressible youth, when contrasted with the sprightliness of the usually dependent Lama, who breathes in the 'diamond air and walk[s] as only a hillman can.' (p.303)

4. Barrie satirizes comments such as this one from Reid's The Giraffe Hunters: 'Impelled by that incomprehensible desire so natural to the hunter - the taking of life, they could not rest quietly at night unless they had killed something during the day' (in McKenzie, 1989, p. 150).

5. The terms 'boy' and 'child' carried different meanings in nineteenth-century British texts. The small child was seen as minimally gendered (or sexually undifferentiated, in Freudian terms) and this is reflected in literary examples like Little Lord Fauntleroy, with small, ferninized boys clinging to the 'tidal pull' of 'primal symbiosis'. Somewhere around the age of seven the child achieved a gender, without losing the ramifications of the link with 'child'. Around the age of fourteen, with the onset of puberty, the 'boy' stage overlapped with 'youth' and began the process of exchanging childish vacancy for manly meaning. Kim is placed within the period of 'boy/youth' yet retains the aura of latency even at 17. Peter Pan is indubitably prepubescent, still blessed with his 'little pearls' of baby teeth. Miles is depicted initially as emerging from the sexually undifferentiated stage, but his exposure to what might be termed the sexual, constructs The Turn of the Screw as a text for adults (see Richardson, 1993).

\section{REFERENCES}

Auerbach, Nina (1989) 'Alice and Wonderland: a curious child', in Victorian Fiction, ed. Harold Bloom. New York, Chelsea House, 403-415.

Avery, Gillian (1975) Childhood's Pattern : A Study of the Heroes and Heroines of Children's Fiction 1770 - 1950. London, Hodder and Stoughton.

Bartie, James (1994) Peter Pan. Harmondsworth, Penguin (1911).

Blake, Kathleen (1977) 'The Sea-Dream: Peter Pan and Treasure Island', Children's Literature, 6, 165-181.

Boehmer, Elleke (1995) Colonial and Postcolonial Literature. Oxford, Oxford University Press.

Carpenter, Humphrey and Prichard, Mari (1984) Oxford Companion to Children's Literature. Oxford, Oxford University Press.

Coveney, Peter (1967) The Image of Childhood. Harmondsworth, Penguin.

Cranny-Francis, Anne (1992) Engendering Fiction: Analysing Gender in the Production and Reception of Texts. Kensington, New South Wales University Press.

Dixon, Robert (1995) Writing the Colonial Adventure : Race, Gender and Nation in Anglo-Australian Popular Fiction, 1875-1914. Cambridge, Cambridge University Press.

Egan, Michael (1982) 'The Neverland of id: Barrie, Peter Pan and Freud', Children's Literature 10, 37-55.

Fiedler, Leslie (1962) 'The eye of innocence' in Henry Anatole Grunwald, ed., Salinger: a Critical and Personal Portrait. New York, Harper and Row, 218245.

Howarth, Patrick (1973) Play Up and Play the Game : the Heroes of Popular Boy's Fiction. London, Eyre Methuen.

James, Henry (1986) The Aspern Papers and the Turn of the Screw. Harmondsworth, Penguin (1898).

Kincaid, James (1992) Child Loving : the Erotic Child 
and Victorian Culture. New York, Routledge.

Kipling, Rudyard (1996) Kim. Harmondsworth, Penguin (1901).

Lustig, T. J. (1994) Henry James and the Ghostly. Cambridge, Cambridge University Press.

McBratney, John (1992) 'Imperial subjects, imperial space in Kipling's Jungle Book', Victorian Studies $35,3,277-293$.

MacKenzie, John (1989) 'Hunting and the natural world in juvenile literature', in Jeffrey Richards, Imperialism and juvenile literature. Manchester, Manchester University Press, 144-172.

Millett, Kate (1977) Sexual Politics. London, Virago.

Nodelman, Perry (1992) 'The Other: orientalism, colonialism, and children's literature', Children's Literature Association Quarterly, 17, 1, 29-35.

Orgel, Stephen (1996) Impersonations. Cambridge, Cambridge UP.

Phillips, Jerry (1993) 'The Mem Sahib, The Worthy, the Rajah and his minions: Some reflections on the class politics of The Secret Garden', The Lion And The Unicorn, 17, 2, 168-194.

Plotz, Judith (1992) 'The empire of youth: crossing and double-crossing cultural bartiers in Kipling's Kim', in Francelia Butler, Barbara Rosen, Judith Plotz, eds., Children's Literature 20, 111-131.

Richards, Jeffrey (ed.) (1989) Imperialism and juvenile literature. Manchester, Manchester University Press.

Richardson, Alan (1993), 'Reluctant Lords and Lame Princes: engendering the male child in nineteenthcentury juvenile fiction', Children's Literature, 21, 3-19.

Rose, Jacqueline (1992) The Case of Peter Pan, or the Impossibility of Children's Fiction. London, Macmillan.

Showalter, Elaine (1991) Sexual Anarchy: Gender and Culture at the Fin de Siècle. London, Bloomsbury.

\section{BIOGRAPHICAL NOTE}

Lucy Hamilton is currently completing her M.A. in English Literature at Monash University, focusing on Shakespearean film adaptation. She has taught secondary English at Melbourne Girls' Grammar School and a range of subjects and ages in London. She is also working on the construction of masculinity in two small boys.

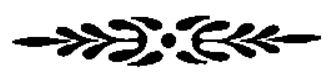

